\title{
ROCK MASS QUALITY EFFECTED BY LINEAMENT USING ROCK MASS RATING (RMR) CASE STUDY FROM FORMER QUARRY SITE
}

\author{
Hamzah Hussin 1, 2*, Nurhazren bt Fauzi 1, Tajul Anuar Jamaluddin² and Mohd Hariri Arifin²
}

\begin{abstract}
${ }^{1}$ Department of Geoscience, Faculty of Earth Science, Universiti Malaysia Kelantan Jeli Campus, Jeli, Kelantan
3School of Environmental Science \& Natural Resources, Faculty of Science \& Technology, Universiti Kebangsaan Malaysia, Bangi, Selangor Corresponding author email: hamzah.h@umk.edu.my
\end{abstract}

This is an open access article distributed under the Creative Commons Attribution License, which permits unrestricted use, distribution, and reproduction in any medium, provided the original work is properly cited

\section{ARTICLE DETAILS}

\section{Article History:}

Received 6 July 2017

Accepted 8 October 2017

Available online 4 November 2017

Keywords:

former quarry, lineament, rock mass quality, rock slope, rock mass rating

\section{ABSTRACT}

Lineament plays major role in stability and strength of rock mass. The presence of lineaments will decrease the strength of rock mass. Lineament can be identified or trace using topographic map, aerial photographs or satellite images. In this research, strength the slope-forming rock mass strength which are affected and non-effected by lineaments was determined by using scan line method. The purpose of this study was to determine the difference of rock mass strength in two difference conditions. A total of 5 rock slopes for each condition were determined. The studied rock slope is located in a former quarry site in Kajang and Sg Long, Selangor, Malaysia. Analysis were done using rock mass rating (RMR). Result of the study show strength of the rock mass which are affected by the lineament is lower compared to those that are not affected by lineament.

\section{INTRODUCTION}

The term of lineament is defining as a significant line of landscape caused by joints and faults, revealing the architecture of the rock basemen $[1,2]$. These features are mappable at various scales, from local to continental. Lineaments are considered to be naturally occurring, mappable linear topographic features on Earth's surface that may be formed by fractures in Earth's crust, which can be joints, faults, or shear zones or linear forms at deeper levels of the crust discernible in aeromagnetic imagery [3-5]. A researcher defined lineament as a pattern in a photograph, map or model of earth's surface or subsurface of earth which is stratigraphically, structurally or geophysical defined that must be linear, continuous, well expressed and related to features of the solid earth [6]. Initially, topographical maps were used in lineament interpretation and the quality of these maps increased with time. The introduction of aerial photos and later on satellite images were important steps in lineament interpretation tools [7-10]. Nowadays, satellite images can easily have downloaded using Google Earth Pro and proved to be a highly effective tool for gathering lineament orientation and spatial distribution data across these wellexposed anticlines $[11,12]$.

The quality of the rock mass which influences the stability of the rock mass is affected by the properties of frequency and orientation of joints, and other discontinuities and its very important to consider not only on threedimensional kinematic release but also in the reduction of rock mass properties $[13,14]$. Rock slope failures was frequently associated with tectonic structure [15-20]. Rock zones containing a high fracture density and/or soft, low cohesion materials can be highly problematic when encountered during excavation. This study presents the analyses effect of lineaments to the rock mass quality of cut slope in the ex-quarry area.

\section{METHODS OF STUDY}

This research was involving desk study, field mapping and data analysis and interpretation. Desk study involves the review of topography maps, geology maps and satellite images to confirm the location and major geological features of the studied slopes. Satellite images downloaded from Google Earth Pro were used in the desk study to identify and interpret the photolineaments and other major geological features.

The interpreted lineament then will be verifying at the field to ensure the interpretation is accurate. The outcrop section which effected by lineament were choosing to conduct detail survey using scan line method by a researcher to determine its rock mass strength [21]. As a comparison, the rock mass strength of non-effected slope by lineament also were determine. Rock mass quality is quantify based on rock mass rating (RMR) by [22].

\section{EXISTING GEOLOGY AND SITE CONDITIONS}

The selected sites in this study are located at Taman Bukit Permai off Jalan Kuari in Cheras, Palm Walk in Bandar Sg. Long, and Kajang Granite Quarry at Kajang district area. This site previously was abundance quarry site. The bedrock geology of the area is essentially consisting of granite, locally known as Kajang Granite and it is also part of the Kuala Lumpur Granite. The granite is composed mainly of medium to coarse-grained, equigranular to moderately porphyritic textured, light grey muscovitebiotite granite. The granite is consisting predominantly of quartz, plagioclase, K-feldspar with some amount of biotite and muscovite (Figure 1).

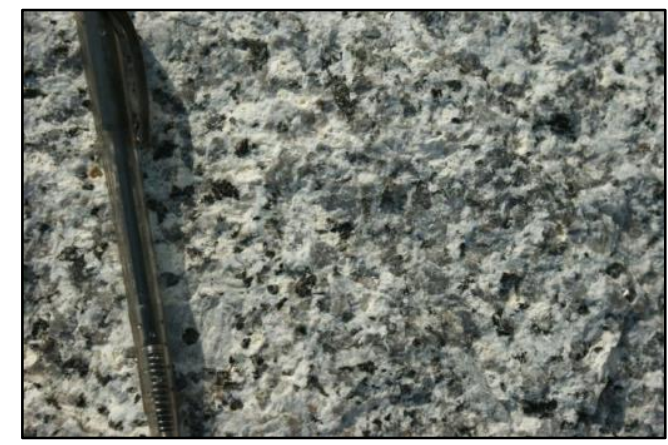


Figure 1: Close-up view of the fresh granite.

The exposed rock masses vary in weathering grade from fresh (grade I) to slightly weathered (grade II), moderately weathered (grade III) and highly weathered (grade IV) rocks. The fresh and slightly weathered rocks are generally exposed at the lower section of the rock cuts, while the moderately and highly weathered rock masses are exposed in the middle and upper sections of the slope (Figure 2). In general, the completely weathered (grade V) rocks and the residual soils (grade VI) layers on the quarry floor have been excavated and removed by past rock quarrying activities. The granite is well jointed and in places is dissected by fault and shear zone. In the studied slopes, discontinuities in the rock mass are mainly found in the form of joints and some localized faults and shear zones (Figures 2). The discontinuity can be found both in fresh rock and highly to completely weathered rocks. Relict discontinuities in the highly weathered rocks can found in almost all slopes.

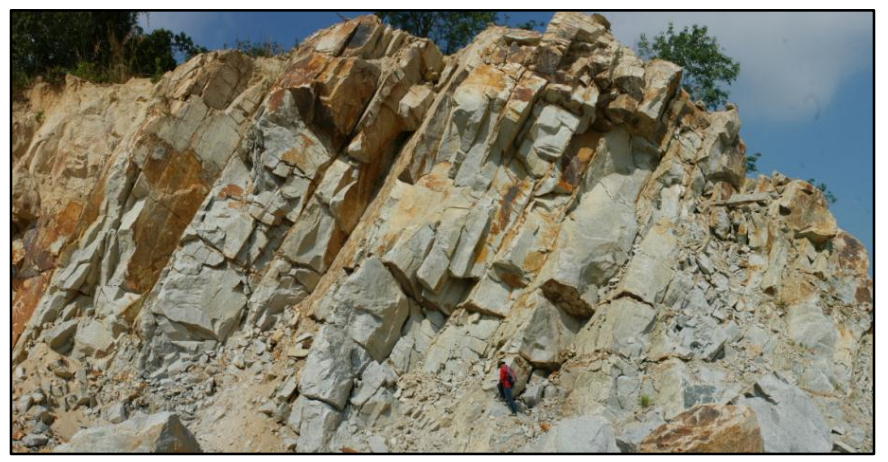

Figure 2: Heavily jointed granite which control potential mode of failure to occur, either in wedge, planar or toppling.

\section{LINEAMENT INTERPRETATION}

Photolineaments study has carried out to determine regional lineament at study and surrounding area. The main focuses of the API are to identify the major structural features of the study area, notably the negative lineament. The lineaments are shown as yellow lines in this figure. In the field, their occurrences are often characterized by fault sliver or zones of heavy fractured rock that oriented in the same direction or running parallel to the identified lineaments.

To visualise the presence of major lineaments which might influenced the overall integrity of the bedrock mass in the hill slope, a photolineament study was carried out by utilising the satellite image downloaded from Google Earth Pro. Although it is well aware that the best method of photolineament study is by using stereopaired aerial photographs of the area, but this was not available during the course of this study. Result for lineament interpretation were discuss as follow.

\subsection{Palm Walk}

The major lineaments at Palm Walk is shown in Figure 3. In the field their occurrences are often characterized by fault slivers or zones of heavily fractured rock that are oriented in the same direction or running parallel to the identified lineaments. In this case study, the rock slopes are dissected predominantly by the NNE-SSW oriented lineaments, and these have been verified in the field by the occurrences of fault zone striking in $\mathrm{NNE} / \mathrm{SSW}$ and dip almost subvertical $\left(80^{\circ}\right)$ to the $\mathrm{E}$ or W (Figure 4).

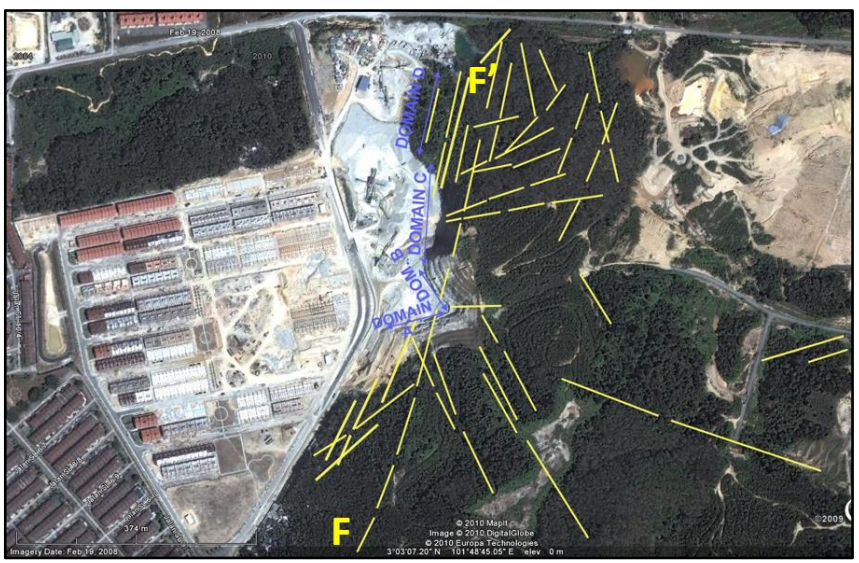

Figure 3: Photolineaments in the granite bedrock of the Palm Walk. Note that the slopes are dissected by major NNE oriented lineaments (F-F').

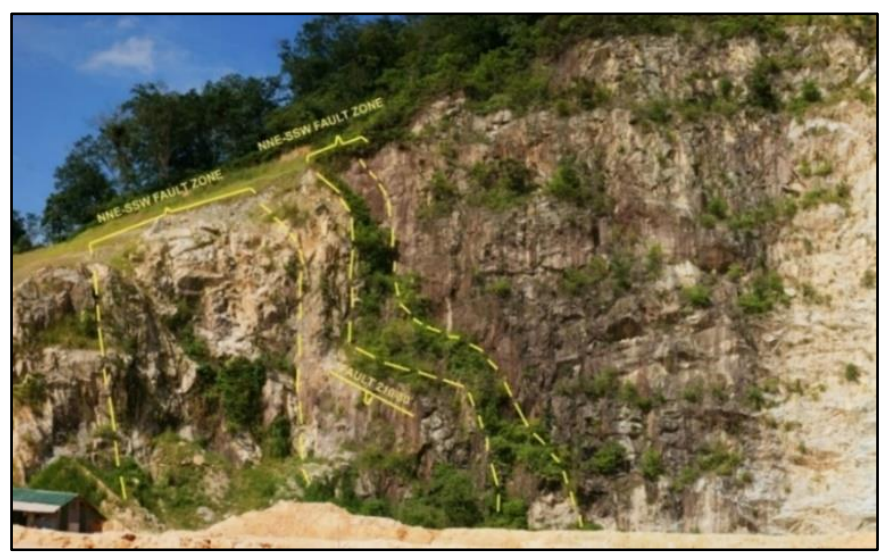

Figure 4: View part of the fracture (fault) zone which represents the major NNE-oriented lineaments that cut through the rock slope at the boundary between Domain C and D.

In Domain D slope, the major NNE-SSW lineament is characterized by series of subvertical and relatively sharp fault planes that controlled the slope faces. In Domain B slope, the NNW-SSE lineament is also found to be represented by a major fault zone of about $2-3$ wide, striking roughly $210 / 80 \mathrm{~W}$. Along this zone, the rock mass is heavily fractured and intensely jointed (Figure 5).

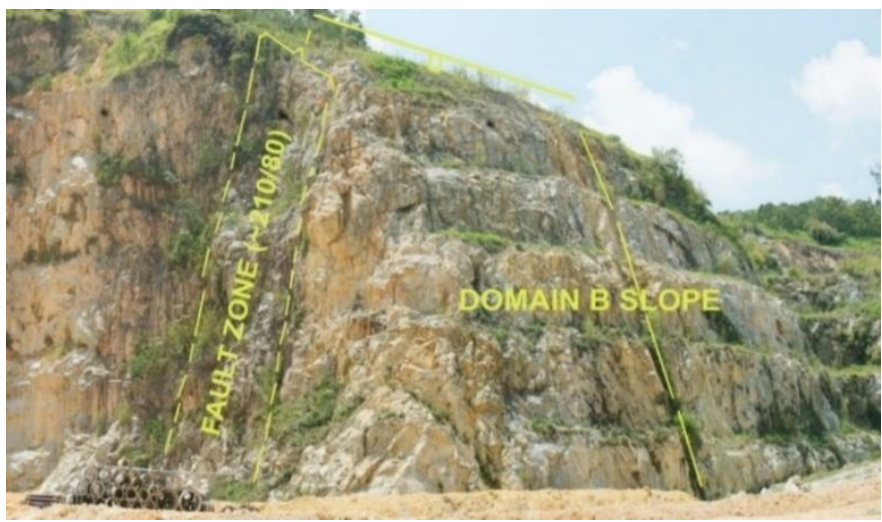

Figure 5: Part of Domain B slope that has been affected by the NNE-SSW lineament which is characterized by a fault zone with intensely fractured rock mass.

Domain A Slope is also partly affected by the major NNE-SSW lineament/fault zone. In the slope, the fault zone is marked by a zone of intensely jointed/fractured rock mass, extending about $20 \mathrm{~m}$ wide, right from the bottom to the top of the slope. Whereas the right and left counterparts, the rock mass is relatively less fractured/jointed (Figure 6).

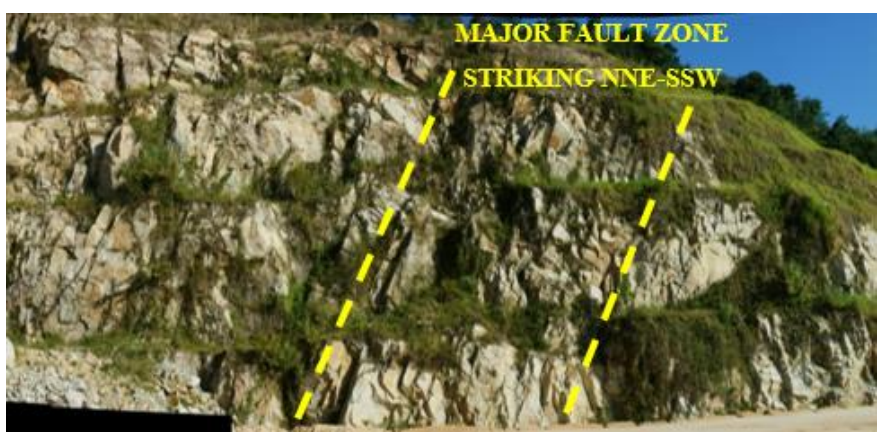

Figure 6: Note the occurrence of heavily jointed/fractured zone (about $15 \mathrm{~m}$ wide) in Domain A rock slope.

\subsection{Goodview Heights}

Results of the photolineament study was shown in Figure 7, which 
suggests that the area is dissected by at least 4 sets of lineaments, mainly strike in NW-SE, almost N-S, NE-SW and ENE-WSW direction. The slope effected by lineament was located at northern part of study area. The existing of lineament was clearly seen at slope with the heavily jointed/fractured zone characteristics (Figure 8). The orientation of lineament is subvertical and the discontinuities persistence was high and its width was $15 \mathrm{~m}$

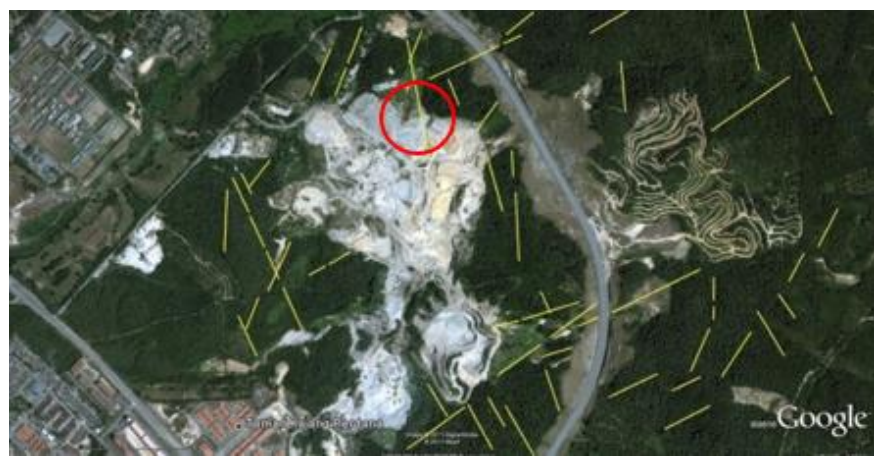

Figure 7: Photolineaments in the vicinity of the study area as interpreted from satellite image of Google Earth. The circle shown present of lineament and its view is shown in Figure 11.

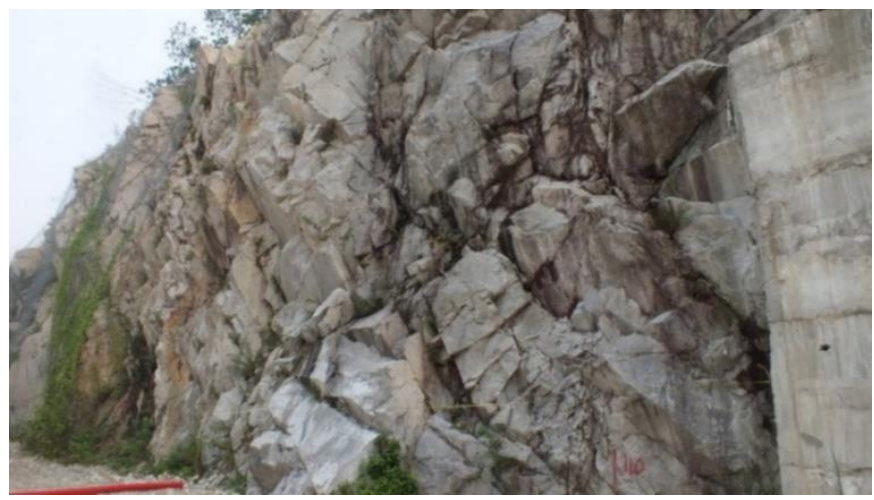

Figure 8: Nature of slope effected by lineament in the Kajang Granite Quarry. The slope is highly fracture with 5 sets of discontinuities.

\subsection{Mayang Kiara}

Results of the photolineament interpretation is show in Figure 9. In the field, their occurrences are often characterized by fault slivers or zones of heavy fractured rock that oriented in the same direction or running parallel to the identified lineaments.

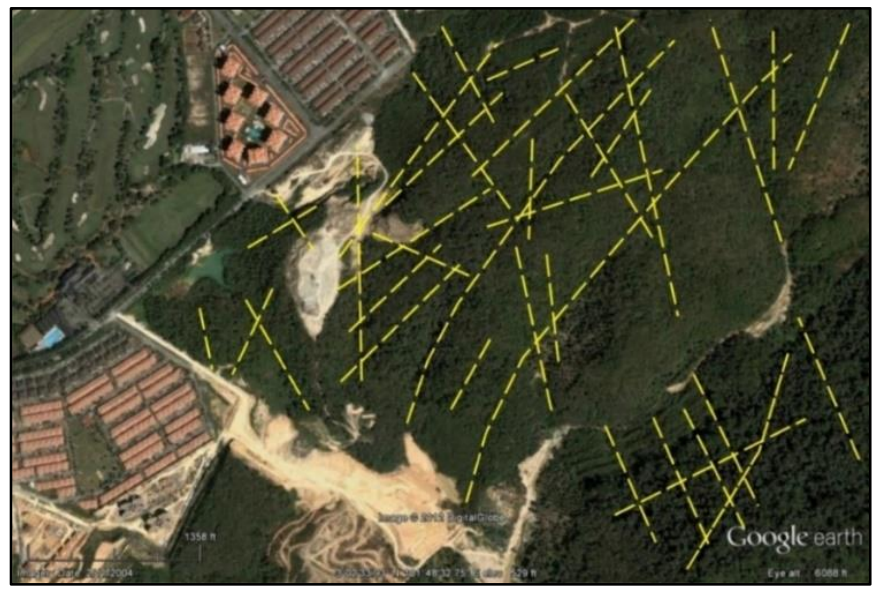

Figure 9: Lineament interpretation from a satellite image (Google Earth, 2004) of the study area.

Result of the photolineament study suggests that the area is dissected by at least 4 sets of lineaments, mainly strike in N-S, NE-SW, NW-SE, and SSENNW directions. Most dominant lineaments are oriented in NW-SE and NE-SW direction. Major lineament oriented SSE-NNW can be found in slope face and can be classified as fault zone. This fault zone is characterized by sudden change of the slope-forming material from hard rock in the right to soil-like material on the left.

\section{LOCATION OF ROCK MASS RATING SURVEY}

Five slopes were selected for detail scan line mapping to determine its rock mass quality using rock mass classification (RMR) as shown in Figure 10. The selected slope was choose based on lineament interpretation.

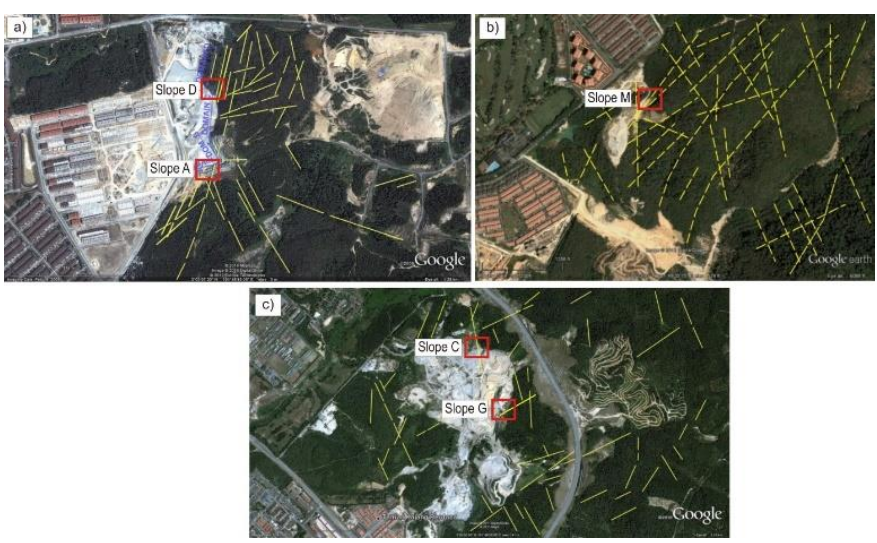

Figure 10: Location for scan line survey at three sites were conducted at rectangular box; a) Palm Walk, b) Mayang Kiara and c) Kajang Granite Quarry

\section{ROCK MASS STRENGTH CLASSIFICATION}

Result of scan line mapping shown effected slope had lower value compared to un-effected slope in rock quality designation (RQD) value and its influence overall rating in rock mass rating. These values prove that lineament will increase spacing between discontinuities and at once decrease its quality. Other discontinuities conditions such as number of discontinuities set, persistence, separation, filling material and roughness were likely alike between both conditions because the measurement were done at nearby location.

The overall result of rock mass rating for each slope were shown in Table 1. Based on the results, the rock mass that affected lineament at Mayang Kiara site had shown the rock mass was classified as poor rock. This affected lineament of the slope site generally had six discontinuities sets with the bad condition. The slope also had two potential of slope failure which are wedge and toppling. Other than that, the characteristics of the discontinuities also affected to the quality of rock mass. These characteristics may partly be explained by the medium-high of discontinuity length, tight separations, and colored infilling of the rock mass gave an influence to the low rating value because all these characteristics could increase the potential of slope failure to occur. The value of Rock Mass Rating (RMR) of 38 indicated that the rock mass was in 'Poor rock' category which could cause some problems of slope stability.

Besides that, the result obtained from the affected lineament for Slope C, at Goodview Height also was classified the rock mass in 'Poor rock' which the value of Rock Mass Rating (RMR) was 40. This slope generally had five discontinuity sets and the orientation of discontinuities had the potential to show the slope failure modes in toppling, wedge and planar. The low rating value obtained from the characteristic of discontinuities such as medium-high of discontinuity length, extreme narrow separations, and cemented infilling of the discontinuities. Hence, the remedial works or stabilization slopes would be more difficult because these were involved a lot of unstable rock blocks.

\section{CONCLUSION}

The present of lineament at rock mass will decrease its rock mass quality compare to un-effected rock mass by lineament. The three slopes can categories as fair slope and two slopes as poor. The lineament present was strongly influence the quality of rock mass strength. The features like heavily jointed/fractured zone, rough surface and the lower quality of RQD are typical condition of slope that effected by lineament. This finding show the important of detail lineament mapping to located its distribution and orientation especially for engineering construction. The present of lineament need to be take note because it's can influence stability of infrastructure for instance slope, tunnel and dam. 
Table 1: Summary of rock mass quality using RMR classification foe effected slope by lineament.

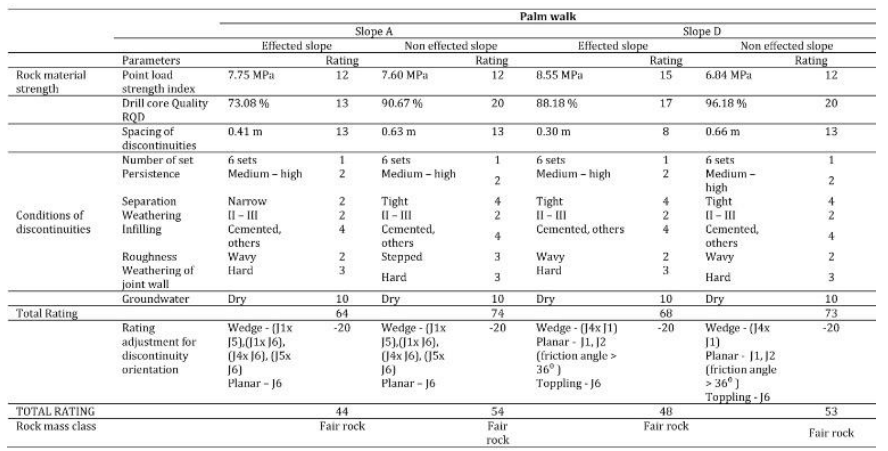

Table 2: Summary of rock mass quality using RMR classification foe effected slope by lineament (cont...).

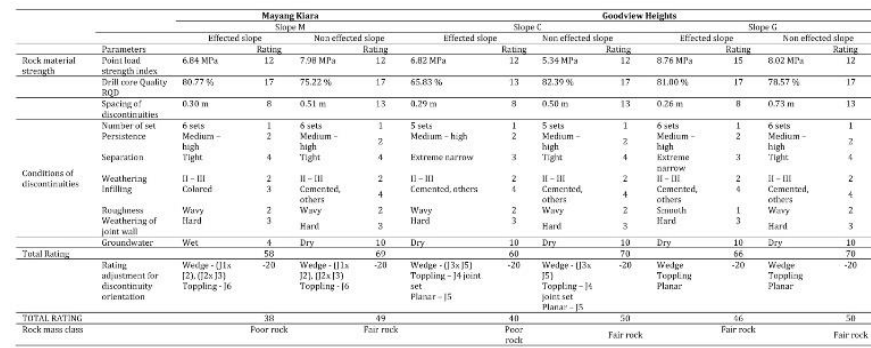

\section{ACKNOWLEDGEMENT}

The authors would like to gratefully acknowledgment to research grant no. R/RAGS/A08.00/01037A/001/2015/000206 provided by Ministry of Higher Education Malaysia and Universiti Malaysia Kelantan for supports the financial of research study.

\section{REFERENCES}

[1] Hobbs, W. H. 1904. Lineaments of the Atlantic border region. Geological Society of America Bulletin, 15 (1), 483-506.

[2] Hobbs, W. H. 1912. Earth features and their meaning: an introduction to geology for the student and the general reader. The Macmillan Company.

[3] Boyer, R., and McQueen, J. 1964. Comparison of mapped rock fractures and airphoto linear features. Photogrammetric Engineering and Remote Sensing, 30 (4), 630-635.

[4] O'leary, D. W., Friedman, J. D., and Pohn, H. A. 1976. Lineament, linear, lineation: some proposed new standards for old terms. Geological Society of America Bulletin, 87 (10), 1463-1469.

[5] Sabins, F. F. 2000. Remote Sensing - Principles and Interpretation. New York: W.H.Freeman and Company.

[6] Caran, C. S., Woodruff Jr, C. M., and Thompson, E. J. 1981. Lineament Analysis and Inference of Geologic Structure--Examples from the Balcones/Ouachita Trend of Texas. Geological Circular, 82 (1), 59-69.

[7] Ghani, M. F. A., Simon, N., Lai, G. T., Mohamed, T. R. T., and Rafek, A. G. 2016. Kajian Ketumpatan Lineamen dalam Penilaian Potensi Jatuhan Batuan di Kawasan Lembah Kinta. Sains Malaysiana, 45 (12), 1887-1896.
[8] Hussin, H., and Jamaluddin, T.A. 2011. Kajian fotograf udara untuk geologi kejuruteraan cerun di kawasan Bukit Chendering, Kuala Terengganu. In National Geoscience Conference (p. 39). Johor Bahru: Persatuan Geologi Malaysia.

[9] Mostafa, M. E., and Bishta, A. Z. 2005. Significance of lineament patterns in rock unit classification and designation: a pilot study on the Gharib-Dara area, northern Eastern Desert, Egypt. International Journal of $\begin{array}{lllll}\text { Remote } & \text { Sensing, } & 26 & \text { (7), } & 1463-1475 .\end{array}$ https://doi.org/10.1080/01431160410001705088

[10] Simon, N., Roslee, R., Lian Marto, N., Akhir, J. M., Rafek, A. G., and Lai, G. T. 2014. Lineaments and their association with landslide occurrences along the Ranau-Tambunan road, Sabah. Electronic Journal of Geotechnical Engineering, 19 C, 645-656. https://doi.org/10.1016/00401951(94)90021-3

[11] Lageson, D. R., Larsen, M.C., Lynn, H. B. and Treadway, W. A. 2012 Applications of Google Earth Pro to fracture and fault studies of Laramide anticlines in the Rocky Mountain foreland. Geological Society of America Special Papers, 492, 209-220.

[12] Rana, N., Chakravarthy, C. P., Nair, R., and Kannan, L. G. 2016 Identification of lineaments using Google tools. In Recent Advances in Rock Engineering (RARE 2016) 124-132. Atlantis Press.

[13] Shuib, M.K. and Jamaluddin, T. A. 2004. A hazard assessment of a granite cut-slope in a hillside developement off Jalan Kuari Cheras, Selangor. Bulletin Geological Society of Malaysia, 49, 1-4.

[14] Brideau, M.-A., Yan, M., and Stead, D. 2009. The role of tectonic damage and brittle rock fracture in the development of large rock slope failures. Geomorphology, 103 (1), 30-49.

[15] Agliardi, F., Crosta, G., and Zanchi, A. 2001. Structural constraints on deep-seated slope deformation kinematics. Engineering Geology, 59 (1), 83-102.

[16] Ambrosi, C., and Crosta, G. B. 2006. Large sackung along major tectonic features in the Central Italian Alps. Engineering Geology, 83 (1) 183-200.

[17] Badger, T. C. 2002. Fracturing within anticlines and its kinematic control on slope stability. Environmental and Engineering Geoscience, 8 (1), 19-33.

[18] Guzzetti, F., Cardinali, M., and Reichenbach, P. 1996. The influence of structural setting and lithology on landslide type and pattern. Environmental \& Engineering Geoscience, 2 (4), 531-555.

[19] Jackson, L. E. 2002. Landslides and landscape evolution in the Rocky Mountains and adjacent Foothills area, southwestern Alberta, Canada. Reviews in Engineering Geology, 15, 325-344.

[20] Kellogg, K. S. 2001. Tectonic controls on a large landslide complex: Williams Fork Mountains near Dillon, Colorado. Geomorphology, 41 (4) 355-368.

[21] Priest, S. D., and Hudson, J. A. 1981. Estimation of discontinuity spacing and trace length using scanline surveys. In International Journal of Rock Mechanics and Mining Sciences and Geomechanics Abstracts, 18, 183-197. Elsevier.

[22] Bieniawski, Z. 1975. Case studies: Prediction of rock mass behavio by the geomechanics classification. In Proceedings of 2nd Australia-New Zealand Conference Geomechanics, Brisbane, 36-41. 